September 2006

\title{
The Significance of the Armenian Genocide after Ninety Years
}

Roger W. Smith

Follow this and additional works at: https://digitalcommons.usf.edu/gsp

\section{Recommended Citation}

Smith, Roger W. (2006) "The Significance of the Armenian Genocide after Ninety Years," Genocide Studies and Prevention: An International Journal: Vol. 1: Iss. 2: Article 2.

Available at: https://digitalcommons.usf.edu/gsp/vol1/iss2/2

This Articles is brought to you for free and open access by the Open Access Journals at Digital Commons @ University of South Florida. It has been accepted for inclusion in Genocide Studies and Prevention: An International Journal by an authorized editor of Digital Commons @ University of South Florida. For more information, please contact digitalcommons@usf.edu. 


\title{
The Significance of the Armenian Genocide after Ninety Years
}

\author{
Roger W. Smith
}

Each genocide provides a foundation for subsequent horrors. Each historical misrepresentation of efforts to exterminate a particular ethnic group increases the likelihood that such efforts will be undertaken again in another time and place.

That over one million Armenian men, women, and children could have been subjected to genocide by the Young Turk government in 1915 and that the world for many years would not remember is profoundly disturbing. Not to remember the suffering of the victims is, above all, a failure of humanity and compassion on our part-a lack of respect and care for fellow humans who have fallen victim to the ultimate outrage against justice, the death of a people. We do not ordinarily think of the dead as having rights, but there is at least one they possess: the right to have the world "hear and learn the truth about the circumstances of their death." 1 This is the one right that, ninety years later, can still be restored to them, and surely we can do no less.

But genocide is not only a crime against a particular people; it is also a crime against humankind. Its inherent potential is to distort and alter the very meaning of "humankind," erasing for all time particular biological and cultural possibilities. Furthermore, for a particular group to claim for itself a right to determine what groups are, in effect, human, possessing the right to life, is a threat to the existence of all other humans. In a period in which genocide has claimed an enormous number of victims, with no end to the carnage in sight, the prevention of future acts of genocide becomes a task for all human beings and governments throughout the world.

Yet without remembrance of past examples of genocide, there will be no sense of urgency in the present, no perceived need to prevent future atrocities. Further, we will cut ourselves off from the knowledge of the causes and sequences of genocide, knowledge that might help prevent other peoples from being subjected to this crime against humanity. The Armenian Genocide is particularly instructive in that it is the prototype for much of the genocide in the twentieth century and the new millennium.

However, when governments look the other way or actively cover up genocide out of short-term self-interest, a signal is sent to would-be perpetrators that they can resolve political and social issues through massive destruction without danger of outside intervention and, through a continual denial of the atrocities, can expect the world to forget these events entirely. Not remembering is not a neutral act-not to remember is to side with the executioners of whole groups and peoples.

The Armenian Genocide, in fact, illuminates with special clarity the dangers inherent in the political manipulation of truth through distortion, denial, intimidation, and economic blackmail. In no other instance has a government gone to such extreme lengths to deny that a massive genocide took place. That democratic governments (the United States and Israel) have supported Turkey in that effort raises significant 
questions about governmental accountability and the role of citizenship in a world in which truth increasingly comes in two forms- "official" and "alleged."

Finally, by helping us to recognize genocide for the radical evil it is, the Armenian example makes possible a transformation of consciousness, one that rejects every manifestation of genocide, including denial, as an instrument of state policy.

Rulers in an earlier age boasted of their annihilation of whole peoples and erected monuments to commemorate their deeds. More recently, however, denial of genocide has become the universal strategy of perpetrators. Those who initiate, or otherwise participate in, genocide typically deny that the events took place, that they bear any responsibility for the destruction, or that the term "genocide" is applicable to what occurred. Denial, unchecked, turns politically- imposed death into a "non-event": in place of words of recognition, indignation, and compassion, there is, with time, only silence. But denial can enter into the very fabric of a society, so that those who come after sustain and even intensify the denial begun by the perpetrators. The most strident and elaborate denial of genocide in history follows this pattern. The Turkish Republic, established in 1923, may not be guilty of physical genocide against Armenians, but it continues today to deny that the Young Turk government engaged in massive destruction of Armenians from 1915 to 1918, resulting in the death of over one million persons and in the elimination of the Armenian people from its homeland of nearly 3,000 years.

Turkey, of course, has also made special efforts in recent years to recognize the Jewish Holocaust and to show compassion for its victims. Yet it has gone to extraordinary lengths to prevent Jews from learning about the Armenian Genocide. The tactic of appealing to moral sentiment, self-interest, and fear has not been without some effect, but Jews might well be suspicious of overtures by a government that is engaged in the massive fabrication of history while the Holocaust itself is being subjected to major distortions and, among "revisionists," its very existence is denied.

Turkey's goal, however, is to prevent recognition of the fact that what was done to the Jews and what was done to the Armenians belong to a common category: genocide. It is especially important for Turkey to stifle this awareness among Jews because for victims of Nazism to state publicly that Armenians and Jews alike have been subjected to genocide carries a kind of moral persuasiveness that non-victims may lack, a power to authenticate the common victimage.

The distortion of history for political ends has significant implications for both the practice of democracy and the protection of human rights. Whatever else democracy means, it means that the government is accountable to the public. But if a government lies to its citizens, acquiesces in the intimidation of scholarship, suppresses freedom of speech, and tolerates attempts by the successor state to control what is taught in public schools, we have entered an Orwellian world where power dictates reality: truth is simply what the government says it is. Under these conditions, accountability is, at best, a fiction-a subversion of democracy on behalf of a regime unwilling to confront its country's past and accept its responsibilities in the present.

Unless genocide is seen as a serious problem, no action will be taken to prevent it. And if previous examples of genocide are consigned to oblivion, the problem of prevention (a complicated and difficult task at best) will lack urgency-distraction, narrow conceptions of interest, and a politics that is blind to the fate of others will take over. Oblivion, however, contributes neither to the role of "innocent bystander" nor to neutrality: if one forgets the atrocities against the Armenians, the Cambodians, the people of East Timor, and others, one is, in effect, rewarding those who have managed 
successfully to use genocide as an instrument of state policy. Oblivion not only reduces the incentive to action, it cuts us off from the very knowledge that might help us to anticipate genocidal situations and to act before the destruction of life begins. If we were aware of the history of genocide in the past ninety years, we might be led to ask, for a range of cases, How did this genocide begin? What were its warning signs? What was the sequence of events? How might this genocide have been prevented or, once in progress, stopped?

The Armenian Genocide is instructive with respect to each of these issues: the question of political will, the reward for successful genocide, and the extraction of useful knowledge from the study of crimes against a subject population. Had the international community focused more on the Armenian case, more active steps to prevent genocide might have been taken. On the other hand, would-be perpetrators of genocide have seen what has happened with the Armenians: they think they can commit genocide and get away with it, and, through denial, eventually erase any recollection of their crime. And by ignoring the Armenian Genocide, we have lost, for too long, knowledge important to the prevention of genocide. No one, including the Jews, foresaw the Holocaust, yet the signs now look inescapable; when mounting evidence of mass death in extermination centers was presented to the Allies and to the media of the day, it simply was not believed. This, after all, was the twentieth century; no government would destroy a people en masse. But, of course, one already had-the trouble was that the Armenian tragedy had become, within only a few years, an "unremembered genocide."

Recognition and remembrance involve more than regard for truth: they express compassion for those who have suffered, respect for their dignity as persons, and revolt against the injustice done to them. In the deepest sense, recognition and remembrance are related not only to what happened but to questions of who we are, what society is, and how life and community can be protected against the visions that would destroy both.

Faced openly, the Armenian Genocide may lead not only to recognition and remembrance but to a deeper awareness of the nature of genocide. The accounts of suffering and brutality that are available to us, especially those of women and children in the caravans of death moving toward the Syrian desert, have the capacity to evoke in the least sentimental of us a sense of rage and shame at what human beings are capable of. From such accounts we gain knowledge that is both existential and cognitive, allowing us to recognize genocide as not only cruelty but radical evil.

In the next stage of awareness one realizes that genocide is a crime not only against a particular group but against humankind itself. Thus, out of solidarity with the victims and consciousness of the nature of genocide, one reaches a third stage in which mass murder as an instrument of state policy is rejected under any and all circumstances, whether attempted by one's own government or by those who have no claim to one's loyalty. The commitments of the third stage of consciousness have important consequences, for they imply that one must not lend support under any circumstances, including denial, to genocide. Further, one must attempt to prevent genocide where possible and, failing in that, must oppose it to the extent that one can. Where past genocides are denied, one has a responsibility to point out and correct such distortions of fact. Where physical genocide ceases but genocide continues at the cultural level, one must oppose it. Where reparation and restitution for past acts of genocide are rejected, one has an obligation to seek justice to the extent possible. 
Faced openly, the Armenian Genocide can also provide knowledge that may assist directly in saving lives in the future. For the Armenian case is the prototype for much of the genocide that followed it, especially that arising from what genocide scholars refer to as the "plural society." These are societies characterized by sharp divisions between ethnic, racial, or religious groups; different degrees of power; and inequality of rights. In such societies, genocide is often resorted to when struggle breaks out over a demand, real or imaginary, for greater equality, partial autonomy, or complete separation. Analyzed from the perspective of a theory of pluralistic genocide, the Armenian example could be particularly suggestive about why a certain type of genocide (the most common form in recent history) occurs and how it might be prevented. In a little over a century in which state-sponsored mass murder has already claimed the lives of some sixty million human beings, the importance of this kind of inquiry speaks for itself.

Yet the scale and frequency of genocide since 1915 can make us feel that the task of prevention is futile. Despair stands in the way of action; knowledge leads to a sense of hopelessness. We cannot bring back to life the dead of the past century or those who have been victims of political mass murder throughout the ages, but, through courage as well as knowledge, we can act to bring about a world free from the scourge of mass killing. In committing ourselves to creating a world of peace, freedom, and mutual respect, we honor the memory of those who have fallen victim to the ultimate crime.

\section{Note}

1. Representative Henry Waxman, speaking for House Joint Resolution 132 for a National Day of Remembrance of the Armenian Genocide of 1915-1923, on 7 August 1987, to the US House of Representatives, 100th Cong., 1st sess., Congressional Record 133 (7 August 1987): H7333. 